\title{
Identifikasi Lokasi Sebaran Pencemaran Air di Kawasan Permukiman Kota Pontianak
}

\author{
Naomi Nessyana Debataraja ${ }^{1}$, Dadan Kusnandar ${ }^{2}$, Rossie Wiedya Nusantara ${ }^{3}$
}

\begin{abstract}
Abstrak
Abstrak Air mempunyai peranan penting bagi aktivitas kehidupan manusia. Aktifitas manusia dalam kehidupan sehari-hari menghasilkan limbah yang berbeda-beda yang dapat mengakibatkan menurunnya kualitas air. Aktifitas manusia dalam kehidupan sehari-hari menghasilkan limbah yang berbeda-beda yang dapat mengakibatkan menurunnya kualitas air. Kota Pontianak sebagai ibukota Kalimantan Barat merupakan daerah yang tingkat pemukimannya cukup padat. Kondisi ini disertai dengan laju pertumbuhan penduduk yang cukup besar. Penelitian ini bertujuan untuk menentukan lokasi untuk pengambilan sampel air dan menentukan variabel sebagai indikator pencemaran air. Teknik pengambilan sampel secara stratified sampling. Variabel yang digunakan dalam menentukan lokasi pengambilan sampel diantaranya adalah batas administrasi, luas wilayah, jumlah penduduk dan kepadatan penduduk. Variabel-variabel tersebut kemudian divisualisasikan dalam bentuk peta tata guna lahan dengan menggunakan Sistem Informasi Geografis (SIG). Diperoleh 58 titik lokasi pengambilan sampel air dan tiga indikator pencemaran air di kawasan permukiman.
\end{abstract}

Kata Kunci: Sistem Informasi Geografis, standar baku mutu, higiene sanitasi, sampling techniques

\section{Pendahuluan}

Kuantitas dan kualitas air di suatu wilayah sangat mempengaruhi kehidupan makhluk hidup. Perubahan dari segi kualitas dan kuantitas air baik permukaan maupun air tanah sangatlah dipengaruhi oleh pola pengelolaan lahan yang ada pada daerah tersebut. Limbah yang dihasilkan dari aktifitas manusia dalam kehidupan sehari-hari dapat menyebabkan terjadinya kemerosotan kualitas air. Limbah yang dibuang memiliki karakteristik yang berbeda yang menentukan derajat kualitas air disekitarnya. Pencemaran air yang disebabkan oleh kualitas bahan pencemar dari sumber pencemar dapat dikatakan sebagai pencemaran kuantitatif air [1]. Limbah yang dihasilkan dari aktifitas kehidupan manusia sangat beragam baik jenis maupun kandungannya. Limbah tersebut dapat berbentuk padatan ataupun cairan; dalam bentuk senyawa organik yang dapat membusuk atau terdegradasi oleh mikroorganisme; bentuk senyawa anorganik seperti sabun, deterjen, sampo, dan bahan pembersih lainnya yang dapat mencemari air tanah[2].

Sebagai ibukota Provinsi Kalimantan Barat, tingkat pemanfatan lahan di Kota Pontianak mengalami peningkatan setiap tahunnya. Hal ini berdampak pada penurunan daya

\footnotetext{
${ }^{12}$ Program Studi Statistika, FMIPA Universitas Tanjungpura

${ }^{3}$ Program Studi Ilmu Tanah, Fakultas Pertanian Universitas Tanjungpura
} 


\section{Naomi Nessyana Debataraja, Dadan Kusnandar, Rossie Wiedya Nusantara}

dukung lahan kota ini. Salah satu bentuk pemanfaatan lahan yang mengalami peningkatan sangat pesat adalah lahan untuk permukiman. Hal ini berkaitan erat dengan pertumbuhan jumlah penduduk. Laju pertumbuhan penduduk di Kota Pontianak setiap tahunnya mencapai 1,65\%. Tingkat kepadatan permukiman berdampak pada kualitas air di Kota Pontianak.

Penginderaan jauh merupakan ilmu dan seni untuk memperoleh informasi tentang suatu objek, daerah, atau fenomena melalui analisis data yang diperoleh dengan suatu alat tanpa kontak langsung dengan objek, daerah, atau fenomena yang dikaji [3]. Data penginderaan jauh mempunyai karakteristik berupa wilayah cakupan wilayah yang luas, dapat menjangkau daerah yang suli dijangkau secara terestris, merekam seluruh kenampakan obyek secara serempak dan apa adanya [4]. Dengan memanfaatkan teknologi ini, pemetaan dapat dilakukan dengan cakupan wilayah yang lebih luas, keakuratan relatif tinggi dan pengerjaannya lebih efisien dibandingkan survey lapangan. Sistem Infromasi Geografis (SIG) dengan kemampuannya dalam memasukkan, menyimpan, mengintegrasikan, memanipulasi, menganalisis dan menampilkan data bereferensi geografis dapat digunakan sebagai alat bantu dalam penentuan suatu lokasi.

Air tanah adalah semua air yang meresap dari permukaan tanah sampai lapisan batuan,air yang terdapat dalam pori-pori, celah batuan dan tanah. Sedangkan air permukaan adalah semua air yang permukaannya terbuka terhadap atmosfer. Apabila kita berbicara tentang uji kualitas air maka menurut kronologi atau tahapan aliran air (dalam siklus air) maka aliran air dalam tanah akan mengalir menuju ketempat yang rendah. Apabila disekelilingnya terdapat saluran baik alami maupun buatan maka air tersebut masuk kesaluran tersebut menjadi air permukaan. Penelitian ini bertujuan untuk menentukan lokasi pengambilan sampel air di Kota Pontianak menggunakan Sistem Informasi Geografis (SIG). Penelitian ini merupakan penelitian awal dalam menentukan sebaran spasial pencemaran air di kawasan permukiman Kota Pontianak.

\section{Metodologi Penelitian}

Penelitian ini dilakukan di Kota Pontianak, Kalimantan Barat. Ibukota Provinsi Kalimantan barat ini mempunyai luas $107,82 \mathrm{~km}^{2}$. Kota ini terletak pada $0^{\circ} 02^{\prime} 24$ " LU $0^{\circ} 01^{\prime} 37^{\prime \prime} \underline{\text { LS }}, 109^{\circ} 16^{\prime} 25^{\prime \prime}$ - 109 $23^{\prime} 04^{\prime \prime}$ BT. Pengambilan lokasi sampel dilakukan dengan metode stratified random sampling. Populasi dikelompokan menjadi sub-sub populasi dengan memperhatikan strata (tingkatan) didalam populasi [5]. Sub-sub populasi dibentuk berdasarkan kriteria daerah yang dialiri oleh anak sungai yang sama merupakan daerah yang homogen. Sampel air yang diambil nantinya adalah sampel air permukaan yang mengalir. Kemudian dari masing-masing sub populasi diambil titik-titik lokasi yang menjadi sampel. Melalui metode ini, terpilih jumlah lokasi sebanyak 58 titik lokasi. Data yang digunakan dalam penelitian adalah data sekunder berupa Peta Rupa Bumi Indonesia, Peta Batas Administrasi Kota Pontianak dan Peta Batas Administrasi Kalimantan Barat.

Pada penelitian ini proses olah data dan analisis SIG menggunakan perangkat lunak ESRI ArcGis 10.2 beserta beberapa extension pelengkapnya. Penelitian ini mempunyai cakupan wilayah yang cukup luas sehingga dengan adanya perangkat lunak ini sangat membantu dalam melakukan analisis data. Analisis SIG digunakan untuk mengevaluasi masing-masing kriteria penilaian tersebut secara spasial. Lokasi pengambilan sampel diperoleh dari hasil tumpang susun (overlay) peta-peta yang telah mengalami proses rektifikasi, yaitu suatu proses melakukan transformasi data dari satu sistem grid menggunakan suatu proses transformasi geometrik.

Penentuan lokasi pengambilan sampel air dilakukan melalui tiga tahap yaitu koreksi geometrik, digitasi, overlay serta analisis lokasi. Koreksi geometrik dilakukan dengan rektifikasi dengan menggunakan sistem koordinat geografis dengan referensi World Geodetic System 1984 (WGS1984). Tahap selanjutnya adalah proses digitasi yaitu mengubah format data jpg ke shp. Objek yang dilakukan digitasi adalah batas administrasi Kota Pontianak sampai ke tingkat kelurahan, jalan, sungai dan anak sungai. Luas wilayah, anak sungai, jumlah penduduk dan 
Naomi Nessyana Debataraja, Dadan Kusnandar, Rossie Wiedya Nusantara

kepadatan penduduk merupakan variabel yang digunakan dalam penelitian ini. Kriteria kepadatan penduduk disajikan pada Tabel 1. Setelah tahap digitasi, kemudian dilakukan overlay data kepadatan penduduk tahun 2016 dan tata guna lahan Kota Pontianak. Tahap terakhir adalah pengambilan lokasi pengambilan sampel air untuk menentukan 58 titik lokasi.

Tabel 1 Kriteria Kepadatan Penduduk Desa Perkotaan

\begin{tabular}{clcl}
\hline No & Klasifikasi (Jiwa) & Nilai & \multicolumn{1}{c}{ Kategori } \\
\hline 1 & $<500$ & 1 & Sangat kurang sekali \\
2 & $500-1.249$ & 2 & Sangat kurang \\
3 & $1.250-2.499$ & 3 & Kurang \\
4 & $2.500-3.999$ & 4 & Sedang \\
5 & $4.000-5.999$ & 5 & Lumayan \\
6 & $6.000-7.499$ & 6 & Padat \\
7 & $7.500-8.499$ & 7 & Sangat padat \\
8 & $8.500<$ & 8 & Sangat padat sekali \\
\hline \multicolumn{2}{l}{ Sumber : BPS (2010) }
\end{tabular}

\section{Hasil dan Pembahasan}

Pada tahap pertama dilakukan rektifikasi peta batas administrasi Kota Pontianak sebagaimana disajikan pada Gambar 1. Peta ini diperoleh dari Peta Rupa Bumi Indonesia dan Peta Batas Administrasi Kota Pontianak. Pada peta ini terdapat informasi batas wilayah administrasi hingga tingkat kelurahan, jaringan anak sungai dan jaringan jalan. Terdapat enam kecamatan di kota Pontianak yaitu Kecamatan Pontianak Timur, Pontianak Tenggara, Pontianak Selatan, Pontianak Barat, Pontianak Utara dan Pontianak Kota. Jumlah kelurahan dari enam kecamatan tersebut sebanyak 29 Kelurahan.

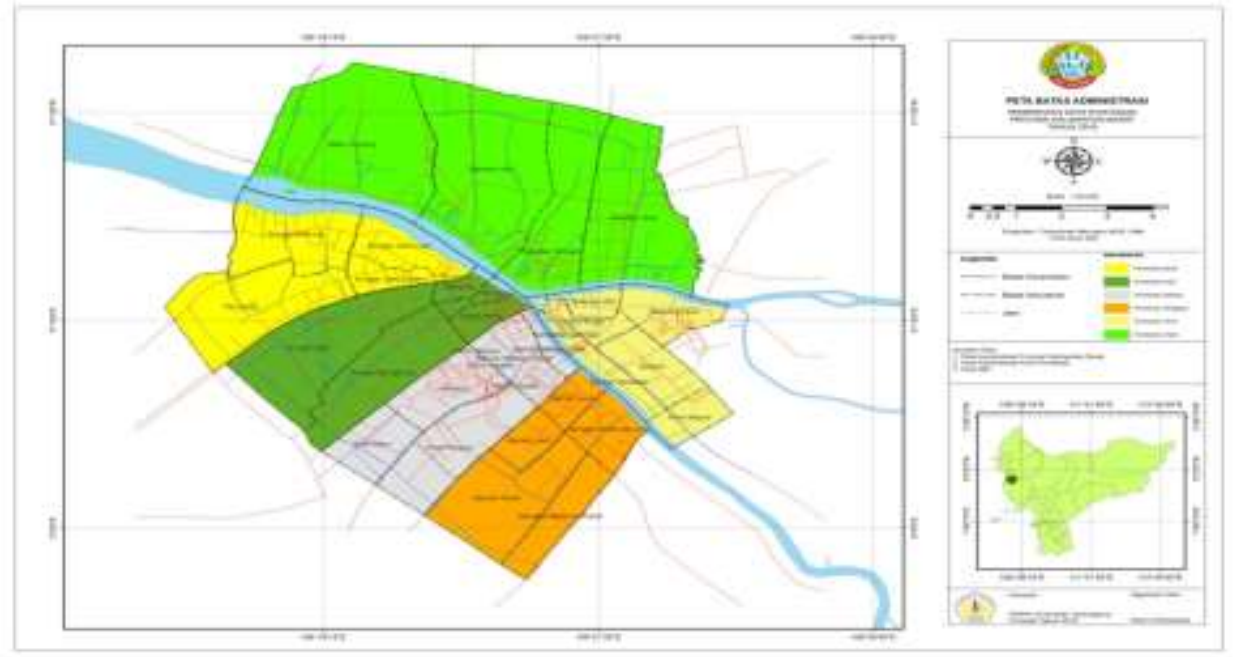

Gambar 1 Peta Batas Administrasi

Peta batas administrasi yang telah diperoleh tadi kemudian ditambahkan informasi mengenai kepadatan penduduk Kota Pontianak tahun 2016 sampai tingkat kelurahan. Hasil overlay tersebut disajikan pada Gambar 2. Dari Gambar 2 dapat dilihat bahwa penduduk Kota Pontianak dibagian utara sebagian besar memiliki kepadatan penduduk yang sedang. Sedangkan kepadatan penduduk sangat padat terdapat di beberapa kelurahan di Pontianak Barat, Pontianak Timur dan Pontianak Kota. Tingkat kepadatan penduduk merupakan kriteria penting dalam penentuan 
Naomi Nessyana Debataraja, Dadan Kusnandar, Rossie Wiedya Nusantara

lokasi pengambilan sampel air. Kepadatan penduduk diperoleh dari jumlah penduduk dibagi dengan luas wilayah.

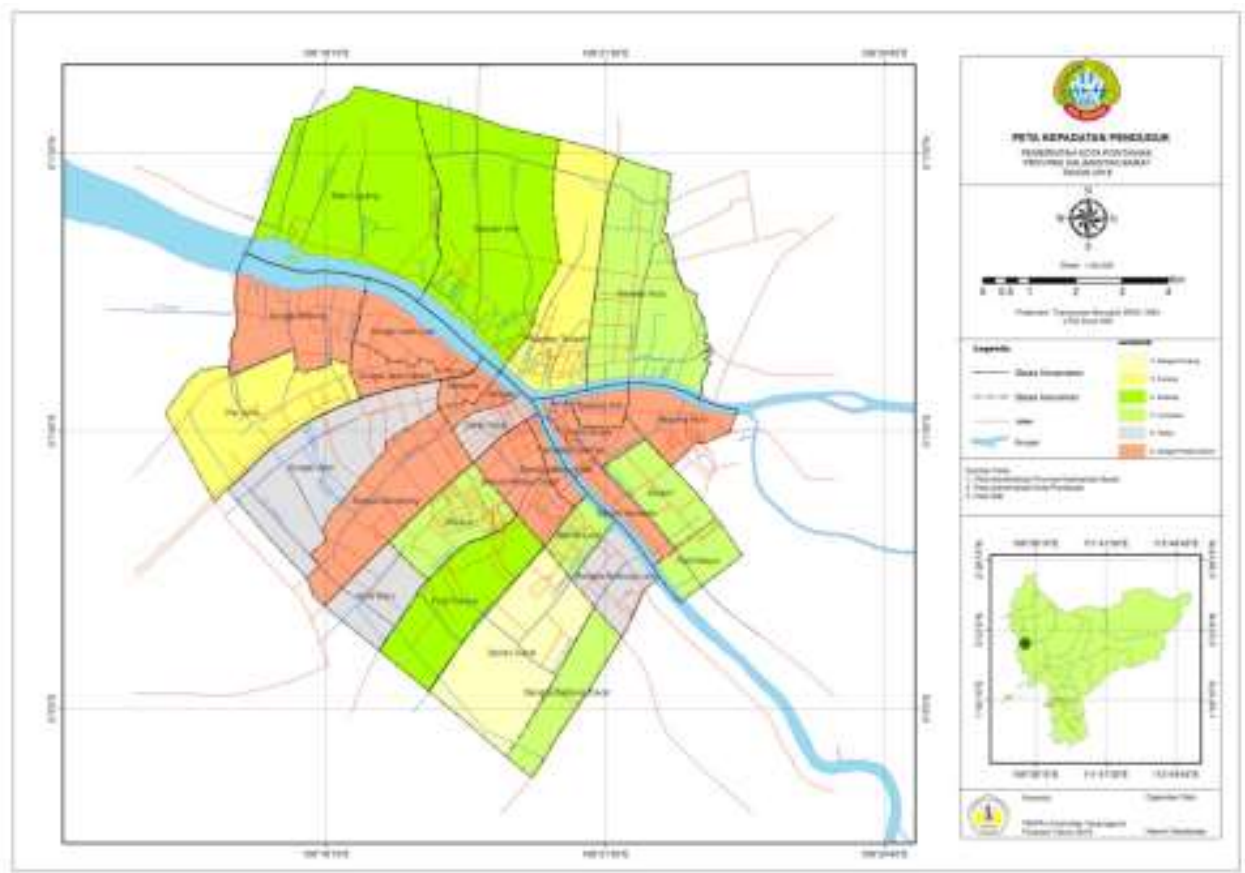

Gambar 2 Peta Kepadatan Penduduk

Tahapan terakhir adalah pengambilan titik lokasi sampel. Pada tahap ini dilakukan proses overlay peta kepadatan penduduk dengan peta tata guna lahan kota Pontianak yang telah dilakukan rektifikasi. Didalam peta tata guna lahan terdapat berbagai variabel, diantaranya: fasilitas kesehatan, fasilitas olahraga, fasilitas pendidikan, jalur hijau, jalur pergudangan, jasa perkantoran, pelabuhan, pemerintahan, permukiman, perdagangan, dll yang menjadi salah satu pertimbangan ketika memilih titik lokasi. Titik-titik diambil dari masing-masing strata yang telah ditetapkan sehingga diperoleh 58 titik sampel yang disajikan pada Gambar 3.
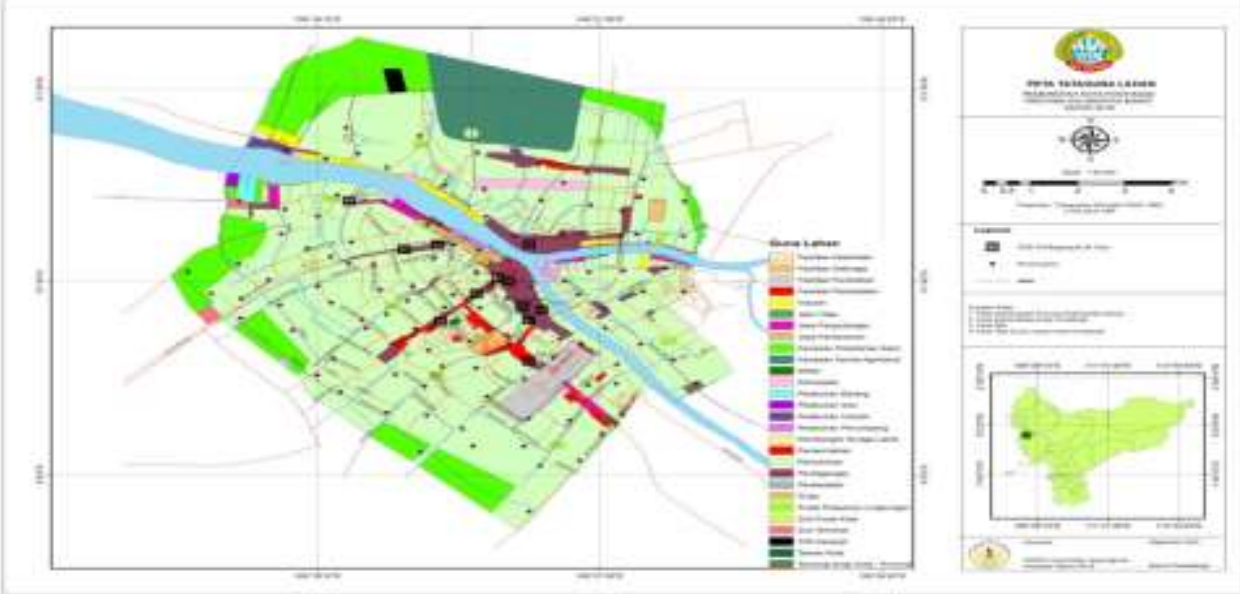

Gambar 3 Peta Titik Lokasi Pengambilan Sampel Air

Dari lokasi yang telah terpilih tersebut, nantinya akan diambil sampel air berdasarkan beberapa indikator. Indikator yang terpilih berdasarkan Peraturan Menteri Kesehatan Republik 
Indonesia Nomor 32 Tahun 2017 tentang standar baku mutu kesehatan lingkungan dan persyaratan kesehatan air untuk keperluan higiene sanitasi. Air untuk keperluan higiene sanitasi digunakan untuk pemeliharaan kebersihan perorangan seperti mandi, sikat gigi, keperluan cuci bahan pangan, peralatan makan dan pakaian [7]. Air untuk keperluan higiene sanitasi dapat digunakan juga sebagai bahan baku air minum. Terdapat 3 indikator yang digunakan yaitu fisik, kimia dan biologi. Indikator fisik meliputi variabel kekeruhan, warna, zat padat terlarut, suhu, rasa dan bau. Indikator biologi meliputi variabel total coliform dan E.coli sedangkan indikator kimia meliputi variabel pH, Besi, Fluorida, kesadahan, Mangan, Nitrat, Nitrit, Sianida, deterjen dan pestisida total.

\section{Kesimpulan}

Dengan memanfaatkan Sistem Informasi Geografis (SIG) dapat ditentukan lokasi pengambilan sampel air permukaan. Lokasi yang direkomendasikan tersebut sejumlah 58 titik sampel.

\section{Ucapan Terimakasih}

Ucapan Terimakasih diberikan kepada Direktorat Pendidikan Tinggi (DIKTI) yang telah memberikan dana penelitian lewat skim Penelitian Dasar Unggulan Perguruan Tinggi dan FMIPA Universitas Tanjungpura yang telah mendukung penelitian ini.

\section{Daftar Pustaka}

[1] Haumahu, J.P., 2010. Effect of Density Settlement on Chemical Quality of Groundwater in Ambon City (Case Study in Alluvial Plain between Batu Merah River and Batu Gantung River). Jurnal Budidaya Pertanian 7: pp. 21-28.

[2] Wardhana, W.A. 2003. Dampak Pencemaran Lingkungan. Jakarta: Penerbit Andi.

[3] Lillesand, T.M., Kieffer, R.W, 1997. Penginderaan Jauh dan Interpretasi Citra. Gadjah Mada University Press. Yogyakarta

[4] Setiawan F, 2010 Aplikasi Penginderaan Jauh dan GIS untuk Penentuan Lokasi TPA Sampah di Kota Surabaya. Prosiding Seminar Nasional Aplikasi Teknologi Informasi 2010 (SNATI 2010).

[5] Sugiarto, 2001. Teknik Sampling. Jakarta: Gramedia Pustaka Utama

[6] BPS, 2010. Peraturan Kepala Badan Pusat Statistik Nomor 37 Tahun 2010 Tentang Klasifikasi Perkotaan dan Perdesaan di Indonesia. Cetakan II. Jakarta

[7] Republik Indonesia, 2017. Peraturan Menteri Kesehatan Republik Indonesia Nomor 32 Tahun 2017 Tentang Standar Baku Mutu Kesehatan Lingkungan dan Persyaratan Kesehatan Air Untuk Keperluan Higiene Sanitasi, Kolam Renang, Solus per Aqua dan Pemandian Umum. Sekretariat Negara. Jakarta 